\title{
The Effect of Service Quality to Customer Satisfaction in Pt. Subang Jaya Lestari Baru
}

\author{
Ivonny Effendy ${ }^{*} \quad$ dan Niken Sulitstyowati \\ Master of Management Study Program, Mercu Buana University, Jakarta Indonesia
}

\begin{abstract}
The purpose of this study is to analyze how service quality can affect customer satisfaction. The dimensions of tangible, reliability, responsiveness, assurance, and empathy are dimensions of service quality. The dimensions of customer satisfaction are attribute related to product, attribute related to service, attribute related to purchase. To answer the problems and research objectives, data were collected from 100 respondents which were research samples where all respondents were consumers of PT. Subang Jaya Lestari Baru. Samples were selected using a total sampling technique. This research is a causal associative type of research using a questionnaire that is measured with a semantic differential scale. Furthermore, the data obtained were analyzed using SEM AMOS analysis. The results showed that the dimension of service quality that has the strongest relationship is assurance with a value of 0.800 , while the dimension of customer satisfaction is the attribute associated with purchase of customer satisfaction with the strongest relationship value of 0.878 . The results of this study indicate that there is a positive and significant influence on Service Quality on customer satisfaction of PT. Subang Jaya Lestari Baru. Keywords : Service Quality, Customer Satisfaction, SEM AMOS
\end{abstract}

DOI: $10.7176 / \mathrm{EJBM} / 12-6-10$

Publication date: February $29^{\text {th }} 2020$

\section{Introduction}

The development of the property business in Indonesia continues to grow from year to year, no exception in the Greater Jakarta area. The development of property investment in Indonesia is predicted to increase rapidly in the next few years. The Indonesian Real Estate Association revealed that the property business growth in Indonesia continues to increase and demand for property, especially housing demand in Indonesia, is currently experiencing a significant increase, even an increase of up to 20\% - 30\%. The Indonesian Real Estate Associate that from 2012 to 2020 the property industry will continue to grow (Jaring news, 2011). The existence of several complaints from consumers and late completion of the complaint, makes the developer must be aware of the element of dissatisfaction received by consumers of the performance of the developer. If this matter is not responded well, it will adversely affect the company's performance, because customer satisfaction is one of the critical success factors of a developer. Therefore, to be able to create a good company requires careful thought about a quality service strategy. The researcher tried to find out the level of satisfaction of the residents of Griya Hegar Asri Housing by conducting a pre-survey to find out the general level of satisfaction with the quality of services provided by PT Subang Jaya Lestari. With this research a theory can be built that can function to explain, predict, and control a symptom, which then respondent results are analyzed using AMOS software.

\section{Literatur Review}

According to Gronroos (in Setiawan, 2015: 455) "Service is an activity or series of activities that are invisible (cannot be touched) that occur as a result of interactions between consumers with employees or other things provided by the service provider organizations that meant to solve to solve the problem of consumers or customers ".The service is given as an act or act of someone or organization to provide satisfaction to the customer of a product or service that they need, therefore the services provided must be of high quality (Kasmir, 2005: 15). Good quality service can lead to customer satisfaction and loyalty. Building quality must start from the needs or desires of customers and end on customer perception (Tjiptono, 2011).

According to Zeithaml \& Bitner (2008) in Saidani and Arifin (2012: 6) explained that what is meant by customer satisfaction is the customer's response to the evaluation of perceived discrepancies between expectations and actual performance of services.

In this study, based on the background, theoretical basis and previous that are relevant and supportive, the authors conpile a framework of thinking referring to the schema in Figure 1 below. The model of thingking consist of 2 (two) variables consisting of service quality to customer satisfaction. The framework of this research is based on the explanation in the study of theory and looks at the formulation of the problem 


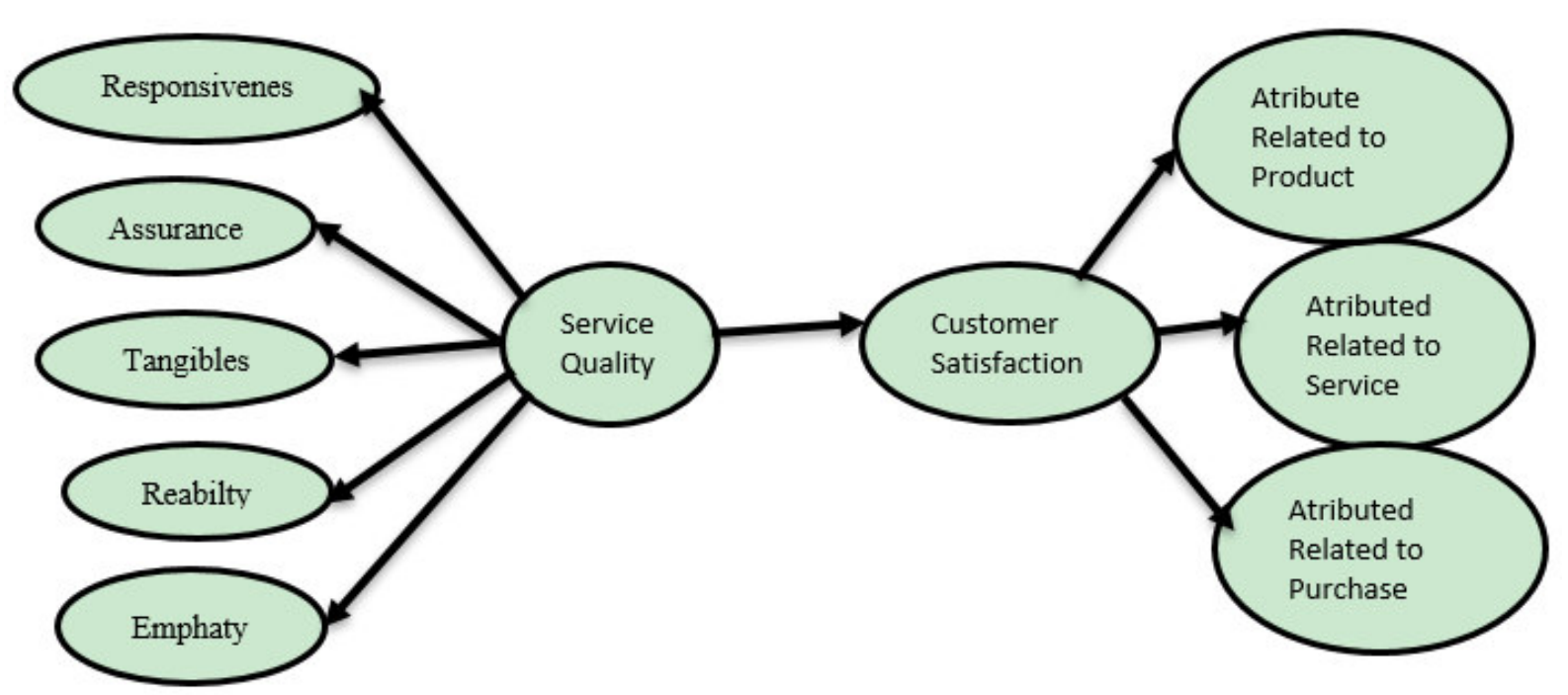

Figure 1. Framework for Thinking

Figure 1 explains that Service Quality variable has 5 dimensions, namely responsiveness, Assurance, tangibles, reability, emphaty. Customer satisfaction variable has 3 dimensions, namely atribute related to product, atribute related to service, attribute related to purchase.

\section{Table 1. Operationalization of X Service Quality}

\begin{tabular}{rr}
\hline Variable & Dime \\
\hline Service Quality & Responsiveness
\end{tabular}

$(\mathrm{X})$

Tangibles

Emphaty

Realibility
Responds well to customers who want to get service

Quick response in providing services

Quick response in providing feedback

Showing a persuasive approach when faced with a problem

Assurance Have timely standards in service

Provide a guarantee of costs in service

Provide a guarantee of legality in service

Office facilities are well maintained

Appearance of employees in serving customers

Ease of service

Have an adequate number of technical personnel

Employees are polite and friendly

Flexibility in terms of communication with customers

Showing sympathy towards customers

Demonstrates his involvement in following up on a problem

Reliability in providing services in accordance with the level of employee knowledge

Reliability in providing skilled services from the sales side

Reliability in providing skilled services in terms of technical sales (presales)

Source : Tjiptono (2011); Sutomo, (2005); Parasuraman (1988); 


\begin{tabular}{|c|c|c|}
\hline & & In \\
\hline Variable & Dimensions & Indicator \\
\hline \multirow{3}{*}{$\begin{array}{l}\text { Customer } \\
\text { Satisfaction } \\
\text { (Y) }\end{array}$} & $\begin{array}{l}\text { Atribute } \\
\text { Related to } \\
\text { Product }\end{array}$ & $\begin{array}{l}\text { The quality of the house sold is in accordance with the price paid } \\
\text { Selling products with good quality } \\
\text { Get a lot of benefitts \& Get lots of convenience to buy a house }\end{array}$ \\
\hline & $\begin{array}{l}\text { Atribute } \\
\text { Related to } \\
\text { Service }\end{array}$ & $\begin{array}{l}\text { Provides a guarantee for every unit of housing it sells } \\
\text { Serve well to consumers who make complaints } \\
\text { Providing goods repair services to consumers } \\
\text { Providing good solutions to customers who have problems with the house } \\
\text { purchased }\end{array}$ \\
\hline & $\begin{array}{l}\text { Atribute } \\
\text { Related to } \\
\text { Purchase }\end{array}$ & $\begin{array}{l}\text { Serve consumers politely when making a home purchase transaction } \\
\text { Provide accurate information to customers for the unit of home purchased } \\
\text { Able to realize customer demand when making purchases of housing units }\end{array}$ \\
\hline
\end{tabular}

Source : Tjiptono (2006); Kaihatu ( 2008) : Giese \& Cote (dalam Tjiptono dan Chandra (2011)

H1: Service Quality has a postitive effect on Customer Satisfaction at PT. Subang Jaya Lestari Baru.

The hypothesis is a temporary answer to the formulation of a research problem, therefore the formulation of a research problem is usually arranged in the form of questions. It is said temporarily, because the answers given are only based on relevant theories, not yet based on empirical facts obtained through data collection. So the hypothesis can also be stated as a theoretical answer to the formulation of a research problem, not yet an empirical answer (Sugiyono, 2010: 93).

\section{Research Method}

This type of research used in this study is causal associative research type, because in this study aims to determine the magnitude of the effect of service quality on customer satisfaction at PT. Subang Jaya Lestari Baru. This research is directed to describe the causal relationship between several situations which are described in variables, and on that basis a general conclusion is drawn. The research variables in this study include the independent variables are The independent variable is service quality $(\mathrm{X})$ and The dependent variable is Customer Satisfaction (Y). Population is a generalization area that consists of objects / subjects that have certain qualities and characteristics determined by researchers to be studied and then drawn conclusions (Sugiyono, 2014: 115). While the sample is part of the number and characteristics possessed by the population (Sugiyono, 2014: 116). all residents of Griya Hegar Asri Housing totaling 134 respondents. The minimum recommended sample size is 100150 (Dachlan, 2014: 144). With a sample size from Consumers PT. Subang Jaya Lestari Baru as many as 100 people are considered sufficient for this research. Primary data is data obtained by researchers directly from the source (Dachlan, 2014: 19). Primary data needed in this study are data obtained from the answers of respondents, namely employees of PT. Subang Jaya Lestari Baru selected from questions raised by researchers through a questionnaire. Data collection techniques in this study were questionnaires used to obtain data on respondents' responses regarding indicators of the variables developed in the study, namely the effect of service quality on customer satisfaction at PT. SJLB. Data analysis techniques are used to interpret and analyze data. In accordance with the multi-dimensional and tiered model that is being developed in this study, the data analysis tool used is the Structural Equation Model (SEM), which is operated through the AMOS program. The stages of analysis are through the Confirmatory Factor Analysis, Average variance Extracted, Construct Reliability, Normality Test, Goodness of Fit Test and Hypotesis Test.

\section{Result and Discussion Characteristic of Respondens}

The number of respondents in study were 100 respondents. Data on the characteristics of respondents can be seen the table below : 
Table 3. Characteristics of Respondents

\begin{tabular}{llcc}
\hline Characteristics & Respondents & Frekuensi & Persentase \\
\hline Profession & Government Employees & 15 & $15 \%$ \\
& Entrepreneur & 7 & $7 \%$ \\
& General Employees & 68 & $68 \%$ \\
Age & $\leq 25$ tahun & & $12 \%$ \\
& $26-35$ tahun & 12 & $76 \%$ \\
& $36-45$ tahun & 76 & $2 \%$ \\
& $\geq 46$ tahun & 2 & $0 \%$ \\
Gender & Man & 0 & $80 \%$ \\
& Woman & & $20 \%$ \\
Education & Senior High School & 80 & $60 \%$ \\
& Diploma & 20 & $27 \%$ \\
& S1 & & $10 \%$ \\
Pasca Sarjana & 60 & $3 \%$ \\
& $\leq$ Rp. 1.000 .000 & 27 & $0 \%$ \\
& Rp 1.000.000 - Rp. 3.000.000 & 10 & $5 \%$ \\
& Rp 3.000.000-Rp 5.000.000 & 3 & $75 \%$ \\
& $\geq$ Rp 5.000.000 & 0 & $20 \%$ \\
\hline
\end{tabular}

Source : Results of data processing 2018

\section{Test Validity and Reability}

\section{Confirmatory Factor Analysis Test}

Confirmatory Factor Analysis (CFA) test results show all indicators of the dimensions and dimensions of the construct obtained probability values at the level of 0.001 and loading estimated values above 0.5 The results of the validity test are shown in Table 4 . The overall construct indicator shows a Critical Ratio (CR) value greater than 1.96, p-value smaller than 0.05 ( $\operatorname{sign} * * *$ means value $<0.001$ ). This shows that all indicators meet the construct validity. Whereas each construct indicator has a proportion of variance with a loading factor $>0.7$. This indicates that all indicators meet convergent validity. So the five indicators of service quality and the three indicators of customer satisfaction can explain well the latent construct, which means it is valid based on the table below:

\begin{tabular}{lllll}
\multicolumn{5}{c}{ Table 4. Validity Test Results } \\
\hline KONSTRUK EKSOGEN & KONSTRUK ENDOGEN & C.R & P & FACTOR LOADING \\
\hline Service quality & Customer satisfaction & 10,318 & $* * *$ & 1,023 \\
\hline \multirow{4}{*}{ Service quality } & Realibility & & $* * *$ &, 790 \\
& Emphaty & 7,985 & $* * *$ &, 732 \\
& Tangible & 8,829 & $* * *$ &, 787 \\
& Assurance & 8,979 & $* * *$ &, 800 \\
& Responsivenes & 8,923 & $* * *$ &, 798 \\
\hline \multirow{2}{*}{ Customer satisfaction } & AtributerelatetoProduct & & $* * *$ &, 812 \\
& Atributerelatetoservice & 11,851 & $* * *$ &, 852 \\
& AtributesrelatetoPurchase & 10,725 & $* * *$ &, 878 \\
\hline
\end{tabular}

Source: Data Processing Results (2018)

Output regression Weight Table 4 shows that the Critical Ratio value of all dimensions of service quality and dimensions of customer satisfaction there is a value greater than 1.96, the value is declared valid. Furthermore, the probability of all indicators and dimensions of service quality and customer satisfaction dimensions of 0.001 $(* * *)$, then all indicators and dimensions are declared valid. Standardized loading values estimate all dimensions of reliability (0.790), empathy (0.732), Tangible (0.787), Assurance (0.800), and Responsiveness (0.798) appearing to be above 0.5 . This shows that the process of data analysis and testing of research models will explain the steps of analysis used in this study. These steps refer to the steps of the SEM analysis process as stated by Dachlan (2014: 203).

\section{Construction Reliability Test}

Construct Reliability (CR) and Average Variance Extracted (AVE) the test results show that all CR values are $\geq$ 0.7 and $\mathrm{CE} \geq 0.5$. Value (CR \& VE) dimensions of service quality ( $0.9 \& 0.6)$; customer satisfaction $(0.9 \& 0.7)$. The resultsof the Construction Reliability Test and 
Extracted Average Variance indicate that the values of all $\mathrm{CR} \geq 0.7$ and $\mathrm{CE} \geq 0.5$ mean that the questionnaire is reliable and valid.

\section{Test for Assumption of Normality and Outliers}

Multivariate normality analysis on AMOS 24 was performed using the criterion ratio criterion (c.r) of multivariate in kurtosis. If the valuev of $\mathrm{cr}$ is in the range between \pm 2.58 it indicates that the data is normally distributed multivariately (haryono, 2017). Normality test results show that there are some c.r values greater than \pm 2.58 .

\section{Tabel. 5 Assumption of Normality}

Assessment of normality (Group number 1)

$\begin{array}{lrrrrrr}\text { Variable } & \min & \max & \text { skew } & \text { c.r. } & \text { kurtosis } & \text { c.r. } \\ \text { APURCH } & 2,750 & 5,000 & , 324 & 1,322 & -, 837 & -1,710 \\ \text { ARS } & 2,500 & 4,750 & , 957 & 3,907 & , 180 & , 368 \\ \text { ARP } & 3,000 & 4,750 & , 433 & 1,769 & -1,158 & -2,363 \\ \text { RPS } & 2,000 & 5,000 & , 420 & 1,714 & -, 053 & -, 108 \\ \text { ASR } & 2,000 & 5,000 & , 553 & 2,256 & -, 045 & -, 092 \\ \text { TANG } & 2,000 & 5,000 & , 170 & , 694 & -, 774 & -1,580 \\ \text { EMPH } & 2,500 & 5,000 & , 338 & 1,382 & -, 598 & -1,220 \\ \text { REAL } & 2,500 & 5,000 & , 195 & , 795 & -, 377 & -, 770 \\ \text { Multivariate } & & & & & 3,282 & 1,297\end{array}$

Source: Data Processing Results (2018)

From table 5 it can be seen that all univariate observation variables contained no CR (Critical Ratio) values for Skewness and kurtosis that were outside the range of 2.58. This it can be said that the univariate normality of research data has been fulfilled. The multivariate kurtosis coefficient is 1,297 or in other words between 2.58 which means that the multivariate normality requirements are fulfilled. Research data that meets multivariate normality means meeting all assumptions of variables meeting univariate and multivariate normality and joint distribution for any pair of variables meeting bivariate normality. In other words, the data in this study were normally distributed.

Goodness of Fit Test

The complete model of the structural test results and model modification is obtainedAssessing Goodness of Fit, the results of SEM model calculations produce a goodness of fit index. Test the suitability of the research model used to test how well the level of goodness of fit is shown in table 6 the table below :

Table 6. Goodness Of fit Test Results

\begin{tabular}{llll}
\hline Goodnessof Fit Indeks & Cut-offValue & Results & Decision \\
\hline Chi Square & $x^{2}$ dengan $\mathrm{df}: 17: \rho: 5 \%=27,58$ & 21,65 & Good Fit \\
\hline Probabilitas & $>0,05$ & 0,20 & Good Fit \\
\hline CMIN/DF & $\leq 3$ & 1,27 & Good Fit \\
\hline GFI & $\geq 0,90$ & 0,95 & Good Fit \\
\hline AGFI & $\geq 0,90$ & 0,90 & Good Fit \\
\hline TLI & $\geq 0,90$ & 0,99 & Good Fit \\
\hline CFI & $\geq 0,90$ & 0,95 & Good Fit \\
\hline RMSEA & $0,03-0,08$ & 0,05 & Good Fit
\end{tabular}

Source: Primary data processed (2018)

Absolute Fit Indices test that compares directly the sample covariance matrix with estimates. One of them is the Chi-square test $\left(\mathrm{x}^{2}\right)$. After modifying the mode, the calculated chi-square values $21.5<$ Chi-square table 27.58 . This shows that be model is valid because the sample coevariance matrix is the same as the estimationmatrix. By lookimg at the significance level $0,000<0.05$ it means that the model becomes fit.

Hypothesis testing

The results of testing the hypotheses proposed in this study are briefly shown in table 4.6. Significance test if it is actually connected with the hypothesis that the test is a test between latent variables in this study, then summarized with the results of the hypothesis test output in table 4.6 below:

Table 4.6 
Table 7. Hypothesis Test Output Results

\begin{tabular}{llllll}
\hline Konstruk Eksogen & Konstruk Endogen & StdEstimate & S.E & C.R & P \\
\hline Service quality & Customer satisfaction & 1,023 & 0,111 & 10,318 & $* * *$ \\
& & 0,790 & & & $* * *$ \\
& Realibility & 0,732 & 0,112 & 7,985 & $* * *$ \\
& Emphaty & 0,787 & 0,139 & 8,829 & $* * *$ \\
& Tangible & 0,800 & 0,145 & 8,979 & $* * *$ \\
& Assurance & 0,798 & 0,146 & 8,923 & $* * *$ \\
& Responsiveness & & & & $* * *$ \\
Customer & Atribute Related to Product & 0,812 & & & $* * *$ \\
satisfaction & Atribute related to Service & 0,852 & 0,078 & 118,851 & $* * *$ \\
& Atribute related to & 0,878 & 0,093 & 10,725 & \\
\hline
\end{tabular}

(*** values indicate the number $<0.001>$

Source: Primary data processed (2018)

Based on table 7 the effect of service quality on customer satisfaction shows the results of hypothesis testing is done by looking at the value of $\mathrm{P}$ is equal to $(* * *)$ which means below 0.05 . it can be concluded that the null hypothesis (H0) which states that zero loading is rejected and the H1 hypothesis of Service Quality has a positive effect on customer satisfaction with a significant level of 0.001 .Standardized parameter value of 1,023 explains that each increase of one unit of service quality variables will increase the value of customer satisfaction by 1,023 . The estimated value at the Standardized Regression Weights output is used to determine the direction and strength of the relationship if the hypothesized influence is proven to be significant.

\section{Conclusions}

The results showed that the five dimensions forming the quality of service proved to have a significant effect on service quality. The strongest dimension in explaining service quality is assurance. This is evident from the results of the study which showed that 1,023 customer satisfaction variables can be explained by service quality variables. From this study it is also known that the three dimensions forming customer satisfaction proved to have a positive and significant effect on customer satisfaction. The strongest dimension in explaining customer satisfaction is the attribute related to purchase. In addition, the results showed that there was a strong and positive influence between service quality variables on customer satisfaction variables at PT. Subang Jaya lestari Baru.

\section{References}

Anderson, E. W., \& Sullivan, M. W. (1993). The antecedents and consequences of customer satisfaction for firms. Anderson, E. W., Fornell, C., \& Lehmann, D. R. (1994). Customer satisfaction, market share, and profitability: Findings from Sweden. Journal of Marketing, 58(3), 53-66.

Anderson, E. W., Fornell, C., \& Rust, R. T. (1997). Customer satisfaction, productivity, and profitability: Differences between goods and services. Marketing Science, 16(2), 129-145.

Aritonang, Lerbin R. (2005). Kepuasan Pelanggan. Jakarta: PT Gramedia Pustaka Utama

Asubonteng, P., McCleary, K. J., \& Swan, J. E. (1996). SERVQUAL revisited: A critical review of service quality. The Journal of Services Marketing, 10(6), 62-81.

Babakus, E., \& Boller, G. W. (1992). An empirical assessment of the SERVQUAL scale. Journal of Business Research, 24(3), 253-268.

Balasubramanian, S., Konana, P., and Menon, N.M. (2003). Customer satisfaction in virtual environments: A study of online investing. Management Science. 49 (7), 871-889.

Basrah Saidani, Samsul Arifin (2012), Pengaruh Kualitas Produk dan Kualitas Layanan terhadap Kepuasan Konsumen dan Minat Beli pada Ranch Market, Jurnal Riset Manajemen Sains Indonesia (JRMSI) Vol 3, No 1.

Bei, L.T., Chiao, Y.C. (2006). The determinants of customer loyalty: An analysis of intangible factors in three service industries. International Journal of Commerce and Management. 16 (3/4), 162-177.

Cronin, J.J. Jr., Brady, M.K., and Hult, G.T. (2000). Assessing the effects of quality, value, and customer satisfaction on consumer behavioral intentions in service environments. Journal of Retailing. 76 (2), 193-218.

Cronin, J.J., Taylor, S.A. (1992). Measuring service quality: a re-examination and extension. Journal of Marketing. $56(3), 55-68$.

Dabholkar, P.A. (1996). Consumer evaluations of new technology-based self-service options: An investigation of alternative modes of service quality. International Journal of Research in Marketing. 13 (1), 29-51.

Danaher, P.J., Rust, R.T. (1996). Indirect benefits from service quality. Quality Management Journal. 3 (2), 63 - 
85.

Eboli, L. \& Mazzulla, G. (2007). “Service quality attributes affecting customer satisfaction for bus transit”. Journal of Public Transportation, 10(3), 21-34.

Esmailpour, M.; Zadeh, M. B. \& Hoseini, E. H. (2012). “The Influence of Service Quality on Customer Satisfaction: Customers of Boushehr Bank Sepah as a Case Study". Interdisciplinary Journal of Contemporary Research in Business, 3(9), 1149-1159

Ferdinand, Augusty, (2006), “Metode Penelitian Manajemen”, Edisi 2, Badan Penerbitan Universitas Diponegoro Ferdinand, Augusty, (2014), "Structural Equation Modeling", Edisi 5, Badan Penerbitan Universitas Diponegoro Finn, D., \& Lamb, C, (1991). An evaluation of SERVQUAL scales in a retail setting. In R. Holman \& M. Solomon (Eds.), Advances in consumer research, (pp. 483-490), San Francisco, CA: Association for Consumer

Fornell, C. (1992). A national customer satisfaction barometer: The Swedish experience. Journal of Marketing. 56 (1), 6-21.

Ghozali, Imam. (2011). Aplikasi Analisis Multivariate dengan Program IBM SPSS 19. Edisi 5. Semarang: Badan Penerbit Universitas Diponegoro

Ghozali, Imam. (2006). Aplikasi Analisis Multivariate dengan program SPSS. Cabang Kebayoran Baru: Badan Penerbit Universitas Diponegoro

Gilbert, D. \& Wong, R. K. (2003). "Passenger expectations and airline services: a Hong Kong based study". Tourism Management, 24(5), 519-532.

Gill, D., Byslma, B., and Ouschan, R. (2007). Customer perceived value in a cellar door visit: The impact on behavioural intentions. International Journal of Wine Business Research. 19 (4), 257-275.

Haryono, Siswoyo, (2017), "Metode SEM Untuk Penelitian Manajemen AMOS,LISREL,PLS”.Penerbit:Luksima Metro Media.

Henning-Thurau, T. (2004). Customer orientation of service employees, its impact on customer satisfaction, commitment, and retention. International Journal of Service Management. 15 (5), 460-478.

Iqbal, Muhammad. 2007. Pelayanan Yang Memuaskan, Jakarta: Penerbit PT. Elex Media Komputindo.

Irma sari Permata, Asriyal (2013), Kesenjangan (Gap) Pelayanan dan Kepuasan Konsumen studi Kasus Minimarket X di Jakarta Timur, Jurnal Liquidity

Meng, J., \& Elliott, K. M. (2009). Investigating structural relationships between service quality, switching costs, and customer satisfaction. Journal of Applied Business and Economics, 9(2), 54-66.

Mitior, Karona Cahya Susena (2015), Analisis Hubungan Pelayanan dengan Kepuasan Pelanggan pada Bengkel Candera Motor di Kaur Utara KabupatenKaur, Jurnal Ilmiah Ekonomi dan Bisnis Fakultas Ekonomi Dehasen Bengkulu.

Nanang, Tasunar, 2006. Kualitas Pelayanan sebagai Strategi Menciptakan Kepuasan pada Pangkalan Pendaratan Ikan ( PPI ) Morodemak. Jurnal Sains Pemasaran Indonesia, Vol. V, No. 1 Mei 2006, h. 41-62.

Pawirosumarto, Suharno. (2016). Pengaruh Kualitas Sistem, Kualitas Informasi dan Kualitas Layanan terhadap Kepuasan Penggguna system E-learning Universitas Mercu Buana. Jurnal Ilmiah Manajemen

Parasuraman, A., Berry, L. L., \& Zeithaml, V. A. (1991). Refinement and reassessment of the SERVQUAL scale.

Parasuraman, A., Zeithaml, V.A., and Malhotra, A. (2005). E-S-QUAL.: A multiple-item scale forassessing electronic service quality. Journal of Service Research. 7 (3), 213-234.

Parasuraman, A., Zeithaml, V.A., and Berry, L.L. (1988). SERVQUAL: A multiple item scale for measuring customer perceptions of service quality. Journal of Retailing. 64 (1), 12-40.

Parasuraman, A., Zeithmal, V.A., and Berry, L.L., (1985). A conceptual model of service qualityand its implications for future research. Journal of Marketing. 49, 41-50

Sutawidjaya,AH, Mochtar, IL \& Nawangsari, LC, Quality Certification and Customer Satisfaction, European Research Studies Jurnal 